\title{
Determination of Putrescine and Cadaverine in the Serum from Lepromatous Leprosy Patients
}

\author{
YOSHINORI TANAKA and TATSUO MORI \\ (Research Institute for Microbial Diseases, Osaka University)
}

In the previous paper, Ishikawa reported that putrescine is always observed in the blood of lepromatous leprosy patient with $M$. leprae in his skin (LA LEPRO 36, 238 (1967)). It is well known that putrescine is one of the ptomains and causes the ptomaine poisoning. So the Ishikawa's report presents a serious problem confronting the lepromatous leorosy patients. In this paper we described the method of determination of putrescine and cadaverine in serum and then the result of measuring these ptomaines in the serum from lepromatous leprosy patients.

The determination of putrescine and cadaverine is as follows;

Serum was extracted with n-butanol by McIntire's method. Butanol layer was acidified with $1 \mathrm{~N}-\mathrm{HCl}$ and then butanol was removed by lyophilization. Lyophilized residue was applied to a small column of Amberlite CG-50 according to the method of D. R. Morris with some modification (cf. Fig. 1).

By the use of Amberlite CG-50 putrescine and cadaverine could not mutually be separated, but could be separated from lysine, histidine, arginine, histamine etc. Standard curve of ninhydrin reaction showed that the concentration of putrescine or cadaverine was in proportion to the rate of ninhydrin reaction. The recovery of putrescine in normal human serum after butanol extraction and column chromatography was about $90 \%$.

About $2 \mathrm{ml}$ (varying from 1.6 to $4.5 \mathrm{ml}$ ) of serum from lepromatous leprosy patient with bacilli in his skin was tested for detection of putrescine and/or cadaverine, but in no case out of seven we did find more than $0.05 \mu$ moles of putrescine and/or cadaverine in the serum.

Ishikawa obtained the serum from $5 \mathrm{ml}$ of blood, so about 2 to $2.5 \mathrm{ml}$ of serum was used for detection of putrescine. The quantity of serum used for determination of putrescine by Ishikawa is almost the same as used by us. We do not believe that the Ishikawa's method is far better than that used by us.

Putrescine and cadaverine are known to be formed by decarboxylation from ornithine and lysine respectively in living organisms. From our result we can not decide whether $M$. leprae has decarboxylase activity or not, because the products of this bacillus may be metabolized to non-toxic materials by human enzyme system to maintaine the homeostasis. For example, even if the putrescine is produced, it will perhaps be oxidized by diamine oxidase in human liver. It seems to be necessary to measure directly decarboxylase activity in the bacillus. 


\title{
瀬腫瀬患者血清中のプトレッシンおよび
}

\section{カダベリンの定量}

\author{
田中吉紀森竜男 \\ 大阪大学微生物病研究所㮌部門 \\ （主任 伊藤利根太郎教授） \\ (受付 1971 年 9 月 21 日)
}

\section{緒 言}

さきに，石川12は濑菌（Mycobacterium leprae）保有 癞腫瀬患者 (L-L 患者) 血清中にプトレッシンが存在す ると報告している。

プトレッシンはカダベリン等と共にプトマインと呼ば れ，特に魚肉，獣肉等が腐敗菌によって分解されたとき に現われる。おそらくは腐敗菌の持つ脱炭酸醉素活性に よるものと考えられている。人がそのよらな食物を搨っ たときプトマインは腸管から吸收されて食中毒（プト マイン中毒) の原因となる。もし，L-L 患者血中にプト レッシンが存在するとすれば，一種の中毒症の状態に恒 常化されていることになり，L-L 患者の病態生理学上重 大な問題である。

一方, K. Prabhakaran 等23は癩菌浮遊液, グルタミン 酸，ピリドキサルリン酸，および酢酸緩衝液（pH 5.0）

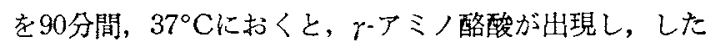
がって，煩菌にはダルタミン酸をケーアミノ酪酸にするグ ルタミン酸脱炭酸䤃素が存在すると報告している。

このようにオルニチン脱炭酸酵素（オルニチン $\rightarrow 70 ト$ レッシン) およびグルタミン酸脱炭酸醳素（グルタミン 酸 $\rightarrow \gamma$ アミノ酪酸）の活性が瀨菌にみられるのであれ

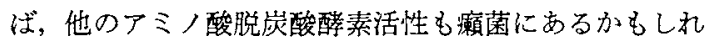
ない。るしそらだとすると,オルニチンからできるプトレ ッシン以外にリジンからカダベリンもできるのではない だろうか。さらにこれらのプトマインと麻腫癭特有の臨 床症状との関䋆はどのようになっているのであろらか。 これらの問題を考えるために，L-L 患者血清中のプトレ ッシン，カダベリンの分離，定量を試みた。

\section{実験材料と方法}

試真：標準物質として、リジン，とスチジン，アルギ ニン (以上和光純葙) プトレッシン (Sigma). カダベリ
ン (東京化成), ヒスタミン (片山化学), スペルミジン （東京化成）を用いた。エタノールは一級品を繁留して 用い，その他の試薬は市販特級品である。

L-L 患者血清 : 大島青松園, 阪大微研㿎部門外来の患 者より埰血，血清分離を行なつた。

正常人血清：阪大附属病院皮䖉科外来にて検查用儿供 せられた血清の一部をプールして用いた。

ブタノール抽出 ${ }^{3)}$ : 血清 $2 \mathrm{ml}$ を生理食塩水で $4.5 \mathrm{ml}$ に 希釈し、アルカリ塩混合物 $1.40 \mathrm{~g}\left(\mathrm{Na}_{2} \mathrm{SO}_{4}, 1.05 \mathrm{~g}\right.$ およ び $\mathrm{Na}_{3} \mathrm{PO}_{4} \cdot 12 \mathrm{H}_{2} \mathrm{O}, 0.35 \mathrm{~g}$ )を加え, 振温溶解後, $\mathrm{n}$ - ブ タノール $5 \mathrm{ml}$ 党加えて 30 分振蕰擋拌し， $2000 \mathrm{rpm} 15$ 分 遠沈する。回収率を上げるためにブタノール抽出は 2 回 行ない,ブタノール層を梨型フラスコに集めて, $\mathrm{IN}-\mathrm{HCl}$ $1 \mathrm{ml}$ を加えて酸性とし，温浴上で吸引蒸発させるか， あるいは凍結乾燥を行なつた。

カラムクロマトグラフィー：Morris 等の方法㣙一 部修正して用いた。ブタノールを除去した残渣を 0.5 $\mathrm{ml}$ の蒸留水に溶かし, カラムにかける。カラムは Am-

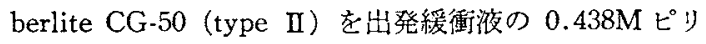
ジンー酶酸緩衝液（pH 5.7）で平衡化したものをつぬて おく。溶出は $0.438 \mathrm{M}$ ピリジン一酶酸綏衝液 $\mathrm{pH} 5.7$ お よび $0.5 \mathrm{M}$ ピりジン一酢酸緩衝液 $\mathrm{pH} 4.4$ で直線的濃度 勾配溶出法によつた。重量式フラクションコレクターで $2 \mathrm{ml}$ ずつ分画した。

ニンヒドリン反応：千谷等によつて修正された $\mathrm{KCN}$ 法5にしたがって行ない, HITACHI-PERKIN·ELMER 139分光光電光度計で, $1 \mathrm{~cm}$ の吸収セルを用いて比色 定量した。

ペーパークロマトグラフィー:フラクションコレクタ 一で分取し、ニンヒドリン反店で得られた各ピークの均 一性を見るために, 各ピークに相当するフラクションを ペーパークロマトグラフィーで調べた。東洋濾紙 No. 51 を用い，ブタノールー酢酸ーピリジン一水 $(4: 1: 1$ ： 


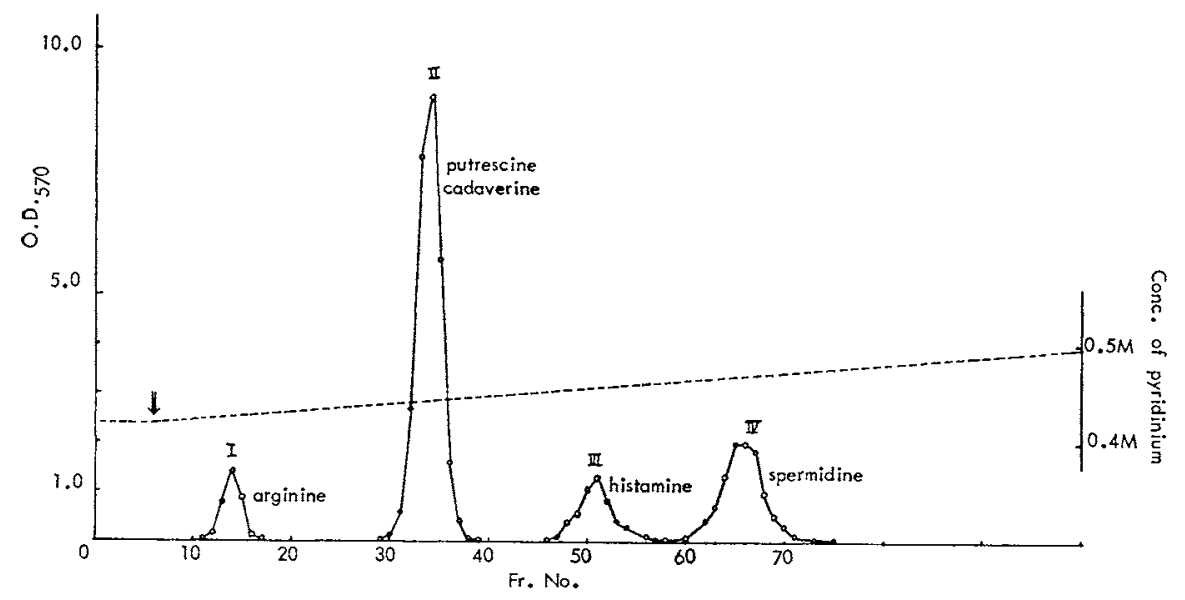

Fig. 1 Column chromatography of the standard solution: resin; Amberlite CG-50 type II pyridinium-form, column; $0.9 \times 11 \mathrm{~cm}$, flow rate; $2 \mathrm{ml} / 1$ fraction $/ 20 \mathrm{~min}$. at room temperature $\left(25-30^{\circ} \mathrm{C}\right)$

start buffer ; $0.438 \mathrm{M}$ pyridinium acetate buffer $\mathrm{pH} 5.7$

linear gradient; $0.438 \mathrm{M}$ pyridinium-acetate buffer $\mathrm{pH} 5.7 \quad 100 \mathrm{ml}$

$0.5 \mathrm{M}$ pyridinium-acetate buffer $\mathrm{pH} 4.4 \quad 100 \mathrm{ml}$

The concentration of pyridinium is shown by the dotted line. The arrow indicates the start point of linear gradient.

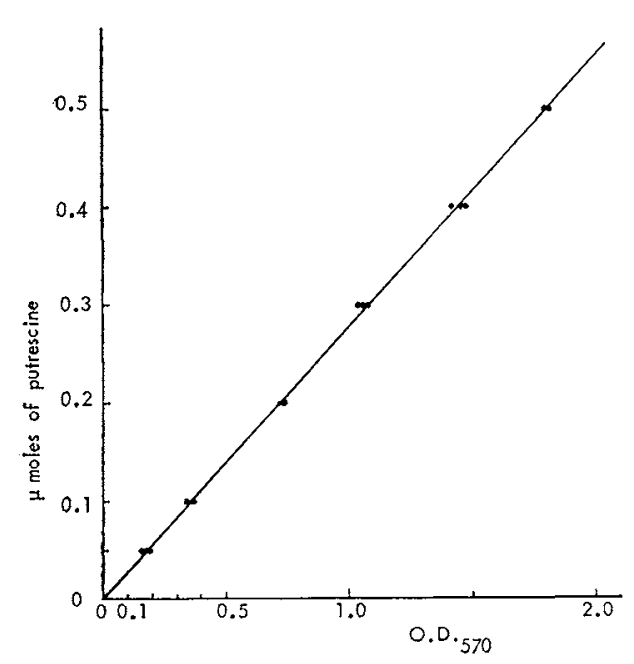

Fig. 2 Standard curve of the putrescine:

Ninhydrin reaction was performed with $0.5 \mathrm{ml}$ of the various concentration of putrescine solution (control; $0.5 \mathrm{ml}$ of distilled water), $0.5 \mathrm{ml}$ of $0.2 \mathrm{M}$ citrate buffer and $1.0 \mathrm{ml}$ of KCN-ninhydrin solution. The reaction mixture was incubated at $100^{\circ} \mathrm{C}$ for $15 \mathrm{~min}$ and then cooled in running water. $3.0 \mathrm{ml}$ of $50 \%$ ethanol was added and the solution was measured optical density at the wave length of $570 \mathrm{~m} \mu$ (HITACHI-PERKIN ELMER 139 spectrophotometer).
2)6の溶媒で上昇法を用いた。発色はニンヒドリン溶 液（ $0.2 \% \mathrm{w} / \mathrm{w}$ 水飽和ブタノール）貲雺，室温一夜放 置でみた。ペーパークロマトグラフィーの一部は $\mathrm{n}$-プ ロパノール・トリエチルアミン・水 (85: $3: 15)$ で展 開し，アルギニンを確認するためにフェナントレンキノ ン反応》による蛨光をみた。

\section{実験結果}

標準物質のカラムクロマトグラフィ一：標準物質をカ ラムクロマトにかけた溶出位置は Fig.10通りである。 各ピークにつけてペーパークロマトを行ない，標準物質 のスポットと比較した結果, Fig. 1中のI）はアルギ二 ン，II）プトレッシンとカダベリン， III） ヒスタミン, IV) スペルミジンが確認できた。さらに別の試みでりジ ンおよびヒスチジンはアルギニンの直前に溶出された。 ニンヒドリン反応によるプトレッシンの標蕉曲線：二 ンヒドリン反応の条件は Fig. 2 に記した通りである。 反応は $100^{\circ} \mathrm{C} 15$ 分間加熱し，流水中で急泠して希㥒液 (50\%エ夕ノール) を加え，O．D．を測定する。実験は triplicate で行ないFig. 2 の各点が測定值である。0.05 $\mu \mathrm{mol}$ から $0.5 \mu \mathrm{mol}$ の範用で直線を示し, $0.5 \mu \mathrm{mol}$ のプトレッシンに対して吸収は，1.80であつた。カダベ リンに関してもほぼ同様の標準曲線が得られた。 


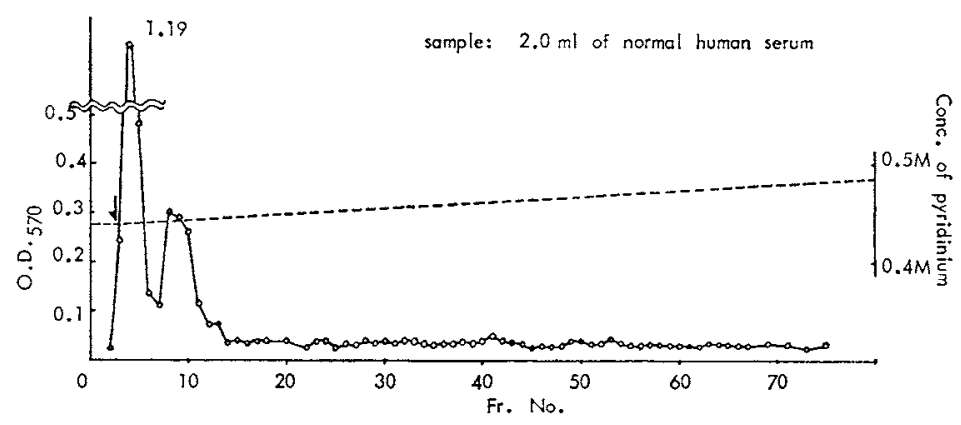

Fig. 3 Column chromatography of the normal human serum: resin; Amberlite CG-50 type II pyridinium-form, column; $0.9 \times 11.5 \mathrm{~cm}$ flow rate; $2 \mathrm{ml} / 1$ fraction $/ 18 \mathrm{~min}$. at room temperature $\left(20-23^{\circ} \mathrm{C}\right)$ The elution procedure was the same as Fig. 1.
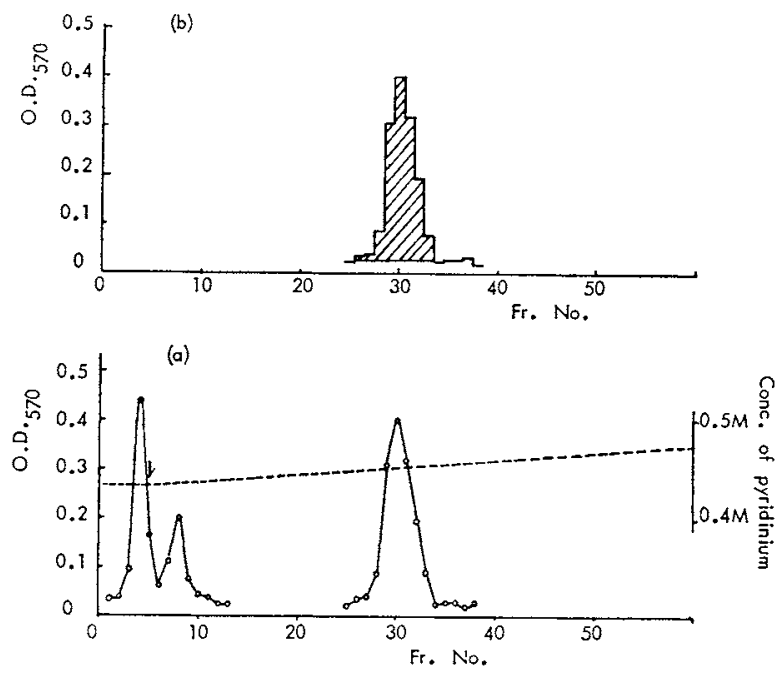

Fig. 4 Column chromatography of the putrescine in the human serum: $2.0 \mathrm{ml}$ of the normal human serum and $2.0 \mu$ moles of putrescine (volume of $200 \mu 1$ ) were taken to the butanol extraction. The butanol was lyophilized and then half of the residue was loaded on the column.

column ; $0.9 \times 10 \mathrm{~cm} \quad$ flow rate $; 2 \mathrm{ml} / 1 \mathrm{fraction} / 18 \mathrm{~min}$. at room temperature (about $15^{\circ} \mathrm{C}$ )

The resin and the elution procedures were as described in Fig. 1.

This elution pattern was shown in Fig. $4(\mathrm{a})$. We calculated the yield of putrescine from the area with the oblique line. (Fig. $4(\mathrm{~b})$ ).

回收率：正常人血清 $2 \mathrm{ml}$ を用いて，ブタノール抽出， カラムクロマトグラフィーを行なつた溶出パターンは Fig. 3 の通りである。素通り物質めるいは塩基性アミノ 酸以外に，プトレッシン，カダベりン，ヒスタミン等の ピークは認められない。さらに $2 \mathrm{ml}$ の正常人衈清に 2.0 $\mu \mathrm{mol}$ のプトレッシンを加え, ブタノール抽出後, 平量
をカラムクロマトグラフィーにかけた。Fig. 4a はその 溶出パターンである。ベースラインより上の部分の面 積(Fig. 4b の斜線部分) を計算し，標準曲線より得ら

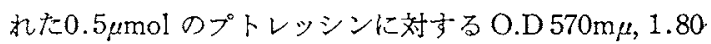
を用いると，加えたプトレッシンの回収率は約 $90 \%$ とな った。 


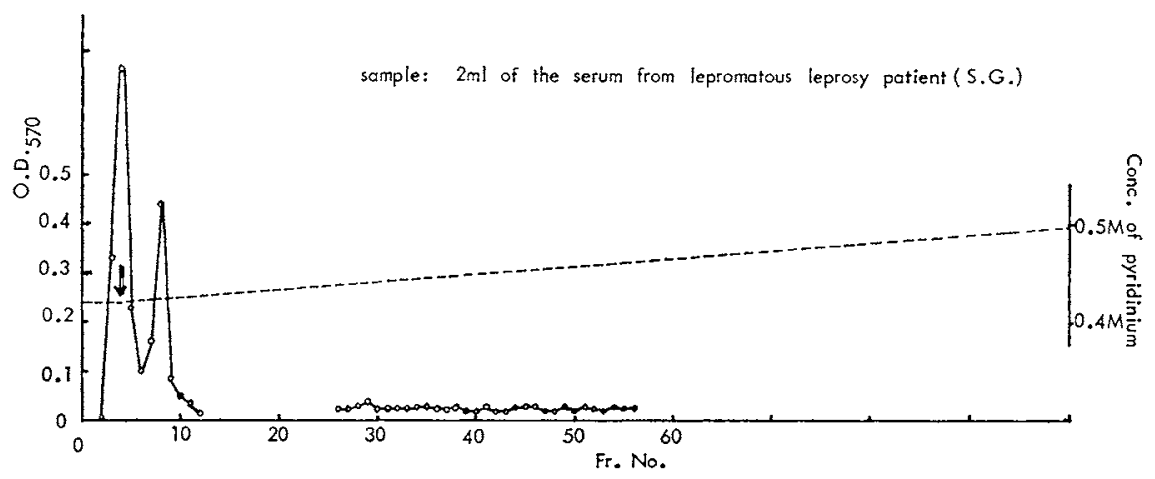

Fig. 5 Column chromatography of the serum from lepromatous leprosy patient: Sample extracted with n-butanol from the serum was loaded on the column. column; $0.9 \times 10.5 \mathrm{~cm}$ flow rate; $2 \mathrm{ml} / 1$ fraction $/ 20 \mathrm{~min}$. at room temperature $\left(15-20^{\circ} \mathrm{C}\right)$

The resin and the elution procedure were as described in Fig. 1.

L-L 患者血清中のプトレッシン，カダベリン，ヒスタ ミンなど：L-L 患者血清 $2 \mathrm{ml}$ から出発したブタノール 抽出，カラムクロマトグラフィーの結果は Fig. 3 と同 様，素通りに近い状態で浴出されてくる物質のほかに， ニンヒドリン陽性物質を認めることはできなかった。

用いた L-L 患者血清量が $1.6 \mathrm{ml}$ から $4.5 \mathrm{ml}$ までい ろいろ変化しているが，全 7 例の L-L 患者血清中にプ トレッシンあるいはカダベリンが認められた症例はなか った。

\section{考察}

直中プトレッシンの定量化を試みた。カラムクロマト グラフィーでは，最初にリジン，ヒスチジン，アルギニ ン等の塩基性アミ/酸が溶出され，統いてプトレッシ ン，カダベリン混合物，ヒスタミン，スペルミジンが順 に現れる。今回われわれの条件では，プトレッシン，力 ダベリン相互の分離は不可能であった。 D. R. Morris 等けはカラムの温度を上げて，これら二者の相互分離に 成功している。

われわれの方法では標準曲線から血清中 $0.05 \mu \mathrm{mol} / \mathrm{ml}$ の物質の検出が可能であるのだが，今回，L-L患者血 清，正常人血清中には共にヒスタミンさえる検出されな かった。

Biochemist's Handbook ${ }^{82}$ によると, ヒスタミンは血 中に $2 \sim 8 \mu \mathrm{g} / 100 \mathrm{ml}$, 平均 $5 \mu \mathrm{g} / 100 \mathrm{ml}$ 存在するとい う。したがって，血清中には平均 $5 \mu \mathrm{g} / 50 \mathrm{ml}$ と考えられ る。ヒスタミンの分子量は 111.2 だから， $5 \mu \mathrm{g} / 50 \mathrm{ml}$ は $0.05 \mu \mathrm{mol} / 50 \mathrm{~mL}$ に相当し，普通，出発材料索数十 $\mathrm{ml}$ にしないと, $0.05 \mu \mathrm{mol}$ の検出は不可能である.今 回の実験では数 ml の血清しか用いていないので，この 量では正常レベルのヒスタミンを検出できなかつたわけ である。

石川は $5 \mathrm{ml}$ の血液がら血清分離しているので，血清 は2 2.5 ml と考えられ，われわれの用いた血清量と ほぼ同量といえるだろう。彼の行なったエーテル抽出， ペーパークロマトグラフィーなどでの損失を考えたと き，むし石川の言うように，L-L 患者衈清中のプトレッ シンがペーパークロマトグラム上でニンヒドリン発色陽 性のスポットとして現われるのであれば，当然われわれ の用いた方法でも陽性になるはずである。

瀬菌にオルニチンおよびリジン脱炭酸酲素活性が存在 するか否かについては，今回の実験からは不明である。 たとえ，それらの醳素活性によって，プトレッシン，カ ダベリンが生成されたとしても，生体の解畫機構，たと えば，肝臟のジアミン酸化酵素活性などによって分解さ れてしまう可能性があるからである。瀬菌の脱炭酸酵素 活性を直接測定するが, L-L 患者の肝豚のジアミン酸化 酵素活性を测定して間接的な証扰集めることが望まし いと思われる。

\section{結論}

1.ブタノール抽出ょよび弱酸性陽イオン交換樹脂を用 いて血中プトレッシン，カダベリンの定量化を行ない， プトレッシンにつルては約 $90 \%$ の回収率を得た。

2.癩腫癩患者血清中にプトレッシン，カダベリンを見 出すことはできなかった。 


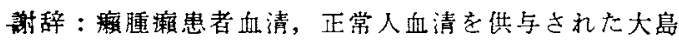
青松園，阪大微研濑部門外来，阪大附属病院皮慮科関係 者に心から感謝いたします。

\section{文献}

1）石川正生：癩腫癞患者血液中のプトレッシンに つけて レプラ 80 238-241(1967)

2) K. Prabhakaran and B.M. Braganca: Glutamic acid decarboxylase activity of $M$. leprae and occurrence of $\gamma$-amino butyric acid in skin lesion of leprosy. Nature $196 \quad 589-590$ (1962)

3) F. C. McIntire, L. W. Roth and J. L. Shaw : The purification of histamine for bioassay. J. Biol. Chem. 170 535-544(1947)
4) D.R. Morris, K.L. Koffron and C. Jokstein : An automated method for polyamine analysis. Anal. Biochem. 30 449-453(1969)

5）千谷晃一，矢追義人：蛋白質・核酸・酵素臨時 増刊，生物化学実験法IV. 70-130(1965)

6) D. Dubin and S.M. Rosenthal : The acetylation of polyamines in E. coli. J. Biol. chem. 235 776-782(1960)

7) Shigeki Yamada, Harvey A. Itano: Phenanthrenequinone as an analytical reagent for arginine and other monosubstituted guanidines. Biochem. Biophys. Acta 130 538-540 (1966)

8) Biochemist's Handbook edited by Cyril Long 1961 page 852 E\&F. N. SPON Ltd London 